\title{
Pengaruh Cairan Cultur Filtrate Fibroblast (CFF) Terhadap Penyembuhan Luka; Penelitian eksperimental pada Rattus Norvegicus Galur Wistar
}

\author{
Oky Masir*, Menkher Manjas**, Andani Eka Putra***, Salmiah Agus****
}

\begin{abstract}
Abstrak
Latar belakang:Metode penyembuhan luka telah mengalami perkembangan, baik berupa suatu produk atau stimulan terhadap proses biologis tubuh dalam menkompensasi luka. Fibroblas merupakan salah satu komponen penyembuhan yang berperan penting dalam proses fibroplasia. Culture Filtrate Fibroblast (CFF) merupakan hasil kultur fibroblas yang akan dibuktikan efeknya terhadap proses percepatan penyembuhan luka pada penelitian ini. Metode. Penelitian ini menggunakan desain eksperimental dengan metode post test only control group design dan rancangan acak kelompok (RAK) dengan menggunakan tikus putih wistar. Hewan coba dibagi menjadi 4 kelompok, yaitu 2 kelompok perlakuan yang diberikan CFF ke area eksisi luka dan kelompok kontrol yang diberikan larutan $\mathrm{NaCl}$ 0,9\% ke area eksisi luka. Data diolah dengan SPSS 16.0. Data Kategori dianalisa dengan Chi-squared dan data numerik dengan Independent T-test. Hasil. Dari tingkat penyembuhan tidak ditemukan perbedaan pada kedua kelompok, namun perubahan restriksi jaringan lebih besar pada kelompok perlakuan. Pada skor pembentukan kolagen, derajat epitelisasi serta jumlah pembentukan pembuluh darah baru pada hari ke-3 tidak ditemukan perbedaan antara kedua kelompok. Namun pada pengamatan hari ke-7 memperlihatkan pembentukan kolagen, derajat epitelisasi serta jumlah pembentukan pembuluh darah baru lebih banyak pada kelompok perlakuan. Pada fibrosis hari ke-3 dan hari ke-7 memperlihatkan terjadinya fibrosis lebih banyak pada kelompok perlakuan dibanding kontrol. Pada pengamatan terjadinya infeksi hari ke-3 memperlihatkan infeksi lebih sedikit pada kelompok perlakuan dan terjadinya infeksi sama pada hari ke-7. Kesimpulan. CFF memberikan tingkat penyembuhan luka yang lebih baik dibanding $\mathrm{NaCl}$.
\end{abstract}

Kata kunci: $\mathrm{CFF}, \mathrm{NaCl}$ 0,9 \%, tingkat penyembuhan luka.

\section{Abstract}

Background: Wound healing methods have been developed, either a product or a stimulant to the body's biological processes in wound compensation. Fibroblasts is one component that plays an important role in the healing process of fibroplasia. Culture filtrat Fibroblast (CFF) is a result of fibroblast culture to be proven effect on the acceleration of wound healing in this study.Methods. This study used an experimental design method post test only control group design and randomized block design (RBD) by using wistar mice. Experimental animals were divided into 4 groups, the two groups of treatment given to the area of excision wound CFF and the control group were given $0.9 \% \mathrm{NaCl}$ solution to the excision wound area. Data processed with SPSS 16.0. Data were analyzed with categories Chi squared and numerical data by the Independent T-test.Result. From degree of wound healing is not found differences in both groups, but the changes in the network restriction greater in the treatment group. The score formation of collagen, the degree of epithelialization and the amount of neovascularisation formation at 3rd day there was no difference between the two groups. However, the observation of 7 th day shows the formation of collagen, the degree of epithelialization and the amount of neovascularisation formation more in the treatment group. On the 3rd day fibrosis and 7th day showed more fibrosis in the treatment group compared to controls. In observation of the 3rd day infection showed fewer infections in the treatment group and the same infection between the two group at 7th day.Conclusion. CFF give wound healing better than $\mathrm{NaCl}$.

Keywords:CFF, $\mathrm{NaCl} 0,9 \%$, degree of wound healing.

Affiliasi penulis : Oky Masir

Korespondensi :Bagian bedah FK. Unand/ RS. DR. M. Djamil

Padang, Bagian Mikrobiologi FK. Unand,Bagian Patologi Anatomi FK Unand. Email :okynasir@gmail.com

\section{Pendahuluan}

Luka adalah diskontinuitas dari suatu jaringan. $^{1}$ Angka kejadian luka memiliki prevalensi mencapai jutaan kasus per tahunnya. Hasil penyembuhan luka yang terganggu seperti luka akut yang penanganannya terlambat dan luka kronis pada umumnya luka tersebut akan gagal untuk maju ke tahapan penyembuhan luka yang normal. Luka tersebut seringkali memasuki kondisi imflamasi patologis karena proses tertunda, tidak lengkap atau proses penyembuhan luka yang tak terkoordinasi. Pada luka kronis seperti ulkus yang berhubungan dengan iskemia, diabetes Melitus dan penyakit stasis vena. Luka yang tidak sembuh mempengaruhi sekitar 3 sampai 6 juta masyarakat di Amerika Serikat, dimana $85 \%$ dijumpai pada usia diatas 65 tahun. Luka yang tidak sembuh mengakibatkan tingginya biaya kesehatan yang dikeluarkan sekitar 3 milyar USD per tahu. ${ }^{2}$

Metode penyembuhan luka telah mengalami perkembangan beberapa tahun terakhir. Metode yang dikembangkan berupa suatu produk atau stimulant terhadap proses biologis tubuh dalam menkompensasi luka melalui beberapa tahapan: hemostasis, inflamasi, proliferasi, dan 
remodeling. ${ }^{3}$ Sasaran dalam proses biologis tubuh menkompensasi luka adalah komponen-komponen yang berperan dalam tahapan penyembuhan luka.

Fibroblas merupakan salah satu komponen penyembuhan luka berupa sel yang terdistribusi secara luas di jaringan ikat, memproduksi substansi precursor kolagen, serat elastis, dan serat retikuler. ${ }^{4}$ Dalam tahapan penyembuhan luka, fibroblas berperan penting dalam proses fibroplasia. Fibroplasia merupakan suatu proses perbaikan luka yang melibatkan jaringan ikat yang memiliki empat komponen: pembentukan pembuluh darah baru, migrasi dan proliferasi fibroblas, deposisi ECM (extracelluler matrix), dan maturasi serta organisasi jaringan fibrous (remodelling). Dalam empat komponen tersebut, fibroblas berperan dalam proses fibrosis yang melibatkan dua dari komponen di atas, yaitu migrasi dan proliferasi fibroblas serta deposisi ECM oleh fibroblast. ${ }^{5}$

Penelitian mengenai pengkulturan fibroblas pernah dilakukan dengan menggunakan lidah buaya (aloe vera) pada kultur fibroblas embrio ayam. ${ }^{6}$ Namun belum ada pembuktian penggunaan produk hasil culture filtrate fibroblast dalam mempercepat proses penyembuhan luka. Maka akan dilakukan penelitian penggunaan culture filtrate fibroblast pada tikus putih wistar untuk mendapatkan informasi efek culture filtrate fibroblast dalam mempercepat proses penyembuhan luka.

\section{BAHAN DAN CARA \\ Hewan Coba.}

Hewan coba digunakan tikus putih jantan jenis Wistar. Hewan coba ada 4 kelompok. Masing - masing kelompok berjumlah enam ekor dan dipersiapkan dengan kandang terpisah. Hewan coba di datangkan dan di pelihara di laboratorium farmasi. Pemeliharaan tikus Wistar dilakukan oleh teknisi laboratorium farmasi Universitas Andalas. Hewan coba di beri makan dan minum sesuai kebutuhan. Satu ekor tikus wistar diberi satu kandang agar luka tidak terganggu. Penggunaan hewan coba berdasarkan pedoman etika penelitian hewan coba yang sudah disetujui oleh fakultas kedokteran. Sebelum penelitian dilakukan tikus ditimbang berat badannya dan secara fisik diamati kesehatannya apakah ada yang sakit atau tidak. Jika ada yang sakit maka tikus wistar tersebut dikeluarkan dari penelitian dan diganti dengan tikus wistar yang baru dengan kriteria yang sama. Kemudian hewan coba dilakukan pengkondisian selama 3 hari.

\section{Isolasi Fibroblast dan Preparasi CFF}

Persiapan jaringan kulit tikus dengan pengambilan full thickness pada bagian punggung melalui pencukuran dan prosedur aseptik/ antiseptic. Matikan tikus dengan eter. Tandai jaringan yang akan diambil. Potong jaringan menggunakan Phosfat Buffer Saline (PBS), buang supernatant. Ulangi prosedur tiga kali. Masukkan jaringan kedalam petridish yang telah berisi media DMEM (Gibco), 2\% Penstrep dan 1\% fungizone. Lakukan diseksi jaringan (agregasi) sehingga terbentuk potongan kecil. Pindahkan kedalam flask kultur. Inkubasi dengan kolagenase $(2000 \mathrm{IU} / \mathrm{ml})$ selama 2 hari. Jika agregasi terlihat telah sempurna (terlihat sel yang terpisah menggunakan mikroskop inverted), hentikan proses kolagenase. Sentrifuse 5000 RPM selama 5 menit. Ambil supernatan dan campur dengan DMEM komplet (ditambah FBS $10 \%$, Penstrep dan Fungizone). Pindahkan ke dalam flask kultur. Kultur pada inkubator $\mathrm{CO}_{2} 37^{\circ} \mathrm{C}$ selama 24 jam.

Amati pertumbuhan sel pada flask kultur, identifikasi bahwa sel fibroblast terletak pada bagian permukaan. Ambil secara hati - hati sel permukaan dan lakukan rekultur dengan DMEM komplet. Kultur pada inkubator $\mathrm{CO}_{2} 37^{\circ} \mathrm{C}$ selama 24 jam. Ulangi proses rekultur selama tiga kali pengulangan, sehingga hanya sel fibroblas yang dikultur dengan jumlah banyak (monolayer dan konfluent). Pada rekultur terakhir, lakukan selama 2 hari. Sentrifus 5000 RPM selama 5 menit, supernatan yang mengandung culture filtrate fibroblast (CFF) diambil. Liophilisasi CFF dan resuspensi dengan $10 \mathrm{ml}$ PBS.

\section{Pembuatan Luka Pada Hewan Coba.}

Setelah culture filtrate fibroblast selesai maka diberikan perlakuan sebagai berikut. Tandai daerah yang akan dilukai pada bagian dorsal dengan ukuran $1 \times 1 \mathrm{~cm}$. lakukan anastesi umum pada hewan coba dengan eter secara inhalasi. Lakukan pencukuran bagian dorsal hewan coba lalu desinfeksi dengan memakai povidine iodine $10 \%$. Lakuakan perlukaan pada daerah yang ditandai dengan tehnik pengambilan full thickness skin excisional. Pelukaan dilakukan dengan pisau bedah no. 15. Untuk kelompok Kontrol I diberikan larutan $\mathrm{Nacl} 0,9 \%$ sebanyak 0,5 ml / 24 jam ke area eksisi luka sampai hari ke 5. Untuk kelompok Perlakuan I diberikan CFF $0.3 \mathrm{ml} / 24$ jam ke area eksisi luka sampai hari ke 5. Kelompok Kontrol II diberikan larutan $\mathrm{NaCl} 0,9 \%$ sebanyak $0,9 \%$ sebanyak 0,5 ml/ 24 jam ke area eksisi luka sampai hari ke 7. Dan kelompok Perlakuan II diberikan CFF 0,3 $\mathrm{ml} / 24$ jam ke area eksisi luka sampai hari ke 7. Kemudian dilakukan pengambilan jaringan kulit pada hari ke 5 kelompok Perlakuan I dan Kontrol I, pada hari ke 7 kelompok perlakuan II dan Kontrol II guna pemeriksaan jaringan dibawah mikroskop untuk menilai perbedaan waktu penyembuhan luka, epitelisasi, ketebalan fibrosis, pembentukan pembuluh darah baru dan ada tidaknya infeksi.

\section{Analisa data}

Untuk membandingkan hasil perlakuan antara hewan yang menggunakan produk fibroblast dengan yang tidak menggunakan produk fibroblast dilakukan dengan SPSS 16,0. Data kategori dianalisa dengan chi-squered, data numerik analisa dengan independent T-Test. Tingkat kepercayaan yang digunakan $95 \%$ yang berarti nilai signifikansi yang kurang dari 0,05 dianggap bermakna.

\section{Etika Penelitian}

Karena memakai binatang percobaan, maka untuk penelitian ini binatang tikus diperlakukan dengan layak, kandang yang bersih, cahaya yang cukup serta makanan dan minuman yang cukup. Perlakuan binatang coba yang 
menimbulkan nyeri dilakukan dengan anastesi umum. Seluruh penatalaksanaan hewan percobaan diawasi oleh supervisor.

HASIL

Penelitian telah dilakukan di laboratorium Fakultas Farmasi dan Laboratorium Patologi Anatomi Fakultas Kedokteran Universitas Andalas, pada 24 ekor tikus putih Wistar dengan 2 perlakuan dan 2 kontrol. Pada kelompok pertama 6 tikus sebagai kontrol hari ke 3. Kelompok kedua 6 tikus sebagai perlakuan hari ke 3 . Kelompok ketiga 6 tikus sebagai kontrol hari ke 7 dan kelompok keempat 6 tikus sebagai perlakuan hari ke 7 . Perlakuan diberikan $\mathrm{NaCl}$ 0,9\% lalu diberikan CFF dan kontrol diberikan $\mathrm{NaCl}$ 0,9\%. Pengamatan dilakukan secara makroskopis dan mikroskopis. Pengamatan makroskopis terhadap tingkat penyembuhan yang ditentukan luasnya restriksi luka setelah pemberian CFF atau $\mathrm{NaCl}$. Pengamatan mikroskopis dilakukan oleh seorang ahli patologi terhadap derajat pembentukan kolagen, fibrosis, pembuluh darah baru, epitelisasi dan infeksi.

\section{Tingkat penyembuhan}

Tingkat penyembuhan dinilai berdasarkan perubahan diameter restriksi jaringan luka. Pada penelitian ini ditemukan rerata perubahan restriksi setelah tiga hari pengobatan adalah $1.217 \pm 0.11$ $\mathrm{mm}$ pada kelompok kontrol dan $1.267 \pm 0.08 \mathrm{~mm}$ pada perlakuan. Analisis statistik dengan independent $t$ test tidak memperlihatkan perbedaan tingkat penyembuhan pada kedua kelompok ( $p>$ 0.05). Sebaliknya, pada hari ketujuh ditemukan perubahan restriksi jaringan lebih besar pada kelompok perlakuan, yaitu $2.883 \pm 0.14$ mmberbanding $2.717 \pm 0.09 \mathrm{~mm}$. Analisis statistik memperlihatkan nilai ini berbeda secara bermakna $(p<0.05)$.

Tabel 1. Perubahan restriksi jaringan

\begin{tabular}{cccc}
\hline & Kontrol & Perlakuan & $\mathrm{p}$ \\
\hline $\begin{array}{c}\text { Hari } \\
\text { ketiga }\end{array}$ & $1.217 \pm 0.11$ & $1.267 \pm 0.08$ & 0.411 \\
\hline $\begin{array}{c}\text { Hari } \\
\text { ketujuh }\end{array}$ & $2.717 \pm 0.09$ & $2.883 \pm 0.14$ & 0.044 \\
\hline
\end{tabular}

\section{Pembentukan kolagen}

Pada pengamatan hari ke-3 tidak ditemukan perbedaan skor pembentukan kolagen antara kelompok kontrol dengan perlakuan. Rerata skor kelompok kontrol dan perlakuan sama, yaitu 1 yang berarti tingkat kepadatan kolagen lebih rendah dibanding jaringan normal dan secara statistik tidak bermakna $(p>0,05)$. Pengamatan hari ke-7 memperlihatkan pembentukan kolagen lebih banyak pada kelompok perlakuan yang ditandai dengan lebih tingginya skor pembentukan kolagen pada kelompok perlakuan, namun secara statistik perbedaan ini tidak bermakna (1.67 \pm 0.516 vs $1.83 \pm 0.408, p>0.05$ )

Analisis terhadap kelompok perlakuan menunjukkan terdapat perbedaan tingkat pembentukan kolagen pada hari ke-3 dan ke-7, dimana skor hari ke-7 lebih tinggi dibanding hari ke3. Uji t test berpasangan memperlihatkan adanya perbedaan yang bermakna kedua skor tersebut $(1.00 \pm 0.000$ vs $1.83 \pm 0.408, p<0.05)$. Hasil yang sama juga ditemukan pada kelompok kontrol, dimana skor pembentukan kolagen hari ke-7 lebih baik dibanding hari ke-3 (1.00 \pm 0.000 vs $1.67 \pm$ $0.516, p<0.05)$.

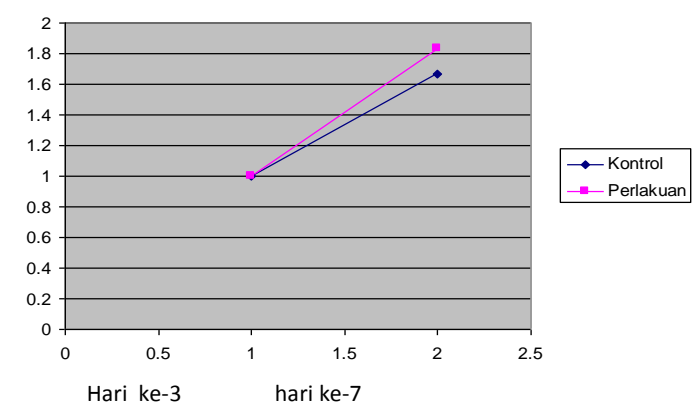

Gambar 1. Perbandingan tingkat pembentukan kolagen

\section{Epitelisasi}

Pada pengamatan hari ke-3 tidak ditemukan perbedaan skor derajat epitelisasi antara kelompok kontrol dengan perlakuan. Rerata skor kelompok kontrol dan perlakuan sama, yaitu 1 yang berarti tidak ada epitelisasi dan secara statistik tidak bermakna $(p>0,05)$. Pengamatan hari ke-7 memperlihatkan derajat epitelisasi lebih banyak pada kelompok perlakuan yang ditandai dengan lebih tingginya skor derajat epitelisasi pada kelompok perlakuan, namun secara statistik perbedaan ini tidak bermakna $(2.33 \pm 0.816$ vs $2.67 \pm 0.516, p>0.05$ )

Analisis terhadap kelompok perlakuan menunjukkan terdapat perbedaan tingkat derajat epitelisasi pada hari ke-3 dan ke-7, dimana skor hari ke-7 lebih tinggi dibanding hari ke-3. Uji t test berpasangan memperlihatkan adanya perbedaan yang bermakna kedua skor tersebut $(1.00 \pm 0.000$ vs $2.67 \pm 0.516, p<0.05)$. Hasil yang sama juga ditemukan pada kelompok kontrol, dimana skor derajat epitelisasi hari ke-7 lebih baik dibanding hari ke-3 $(1.00 \pm 0.000$ vs $2.33 \pm 0.816, p<0.05)$.

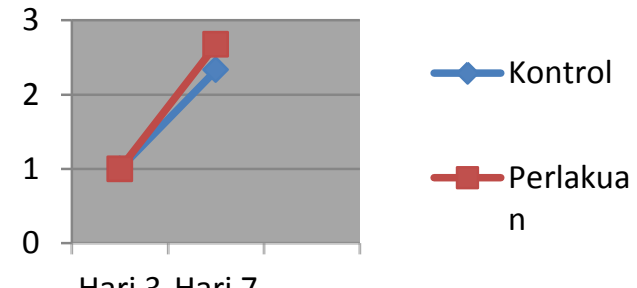

Hari 3 Hari 7

Gambar 2. Perbandingan tingkat derajat epitelisasi 


\section{Pembuluh darah baru}

Pada pengamatan hari ke-3 tidak ditemukan perbedaan skor jumlah pembentukan pembuluh darah baru antara kelompok kontrol dengan perlakuan. Rerata skor kelompok kontrol dan perlakuan sama, yaitu 2,83 yang terdapat 1-2 pembuluh darah baru, namun secara statistik tidak bermakna $(p>0,05)$. Pengamatan hari ke-7 memperlihatkan jumlah pembentukan pembuluh darah baru lebih banyak pada kelompok perlakuan yang ditandai dengan lebih tingginya skor jumlah pembentukan pembuluh darah baru pada kelompok perlakuan, namun secara statistik perbedaan ini bermakna $(2.83 \pm 0.408$ vs $3.00 \pm 0.000, p<0.05)$ Analisis terhadap kelompok perlakuan menunjukkan terdapat perbedaan tingkat jumlah pembentukan pembuluh darah baru pada hari ke-3 dan ke-7, dimana skor hari ke-7 lebih tinggi dibanding hari ke-3. Uji $t$ test berpasangan memperlihatkan tidak ada perbedaan yang bermakna pada kedua skor tersebut $(2.83 \pm 0.408$ vs $3.00 \pm 0.000, p>0.05)$. Hasil berbeda ditemukan pada kelompok kontrol, dimana skor pembuluh darah baru sama antara hari ke-3 dan ke-7, yaitu $2.83 \pm 0.408$.

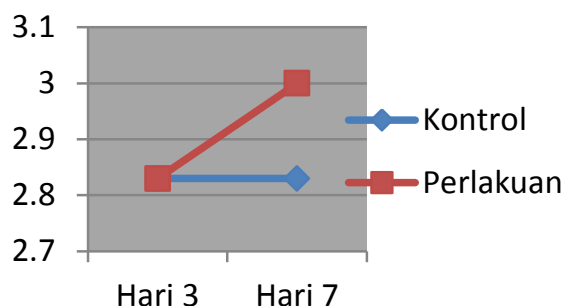

Gambar. 3 Perbandingan tingkat pembentukan pembuluh darah baru

\section{Fibrosis}

Pada pengamatan hari ke-3 ditemukan perbedaan skor terjadinya fibrosis antara kelompok kontrol dengan perlakuan, memperlihatkan fibrosis lebih banyak pada kelompok perlakuan dibanding kelompok kontrol dan secara statistik bermakna $(1.00 \pm 0.000$ vs $1.17 \pm 0.408, p<0.05)$. Pengamatan hari ke-7 memperlihatkan terjadinya fibrosis lebih banyak pada kelompok perlakuan yang ditandai dengan lebih tingginya skor terjadinya fibrosis pada kelompok perlakuan dibanding kontrol $(1,83 \pm 0.408$ vs $2,67 \pm 0.516)$. Analisis dengan independent $t$ test memperlihatkan nilai ini berbeda secara bermakna, namun secara statistik perbedaan ini tidak bermakna $(p>0.05)$

Analisis terhadap kelompok perlakuan menunjukkan terdapat perbedaan terjadinya fibrosis pada hari ke-3 dan ke-7, dimana skor hari ke-7 lebih tinggi dibanding hari ke-3. Uji $t$ test berpasangan memperlihatkan adanya perbedaan yang bermakna kedua skor tersebut $(1.17 \pm 0.408$ vs $2,67 \pm 0.516, p<0.05$ ). Hasil yang sama juga ditemukan pada kelompok kontrol, dimana terjadinya fibrosis hari ke-7 lebih baik dibanding hari ke-3 dan secara statistic bermakna (1.00 \pm 0.000 vs $1,83 \pm 0.408, p<0.05)$.

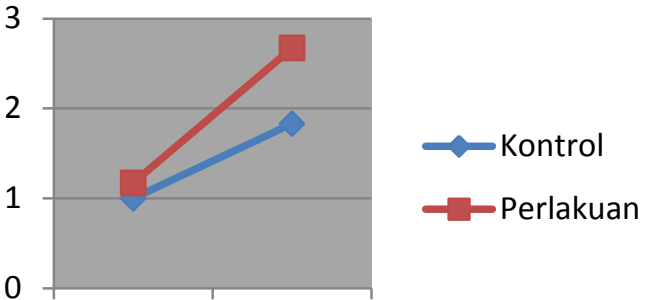

Hari 3 Hari 7

Gambar. 4 Perbandingan tingkat fibrosis

Infeksi

Pada pengamatan hari ke-3 ditemukan perbedaan skor terjadinya infeksi antara kelompok kontrol dengan perlakuan, memperlihatkan infeksi lebih sedikit pada kelompok perlakuan dibanding kelompok kontrol dan secara statistik tidak bermakna (1.33 \pm 0.516 vs $1.83 \pm 0.753, p>0.05$ ). Pengamatan hari ke-7 memperlihatkan terjadinya infeksi kelompok perlakuan sama dengan kelompok kontrol, $(2,83 \pm 0.408$ vs $2,83 \pm 0.408$, $p$ $>0.05$ )

Analisis terhadap kelompok perlakuan menunjukkan terdapat perbedaan terjadinya infeksi pada hari ke-3 dan ke-7, dimana infeksi pada hari ke-7 lebih rendah dibanding hari ke-3. Uji t test berpasangan memperlihatkan adanya perbedaan yang tidak bermakna pada kedua skor tersebut $(1.83 \pm 0.753$ vs $2,83 \pm 0.408, p>0.05)$. Hasil yang sama ditemukan pada kelompok kontrol, dimana terjadinya infeksi hari ke-7 lebih rendah dibanding hari ke-3 namun secara statistik bermakna (1.33 \pm 0.516 vs $2,83 \pm 0.408, p<0.05)$.

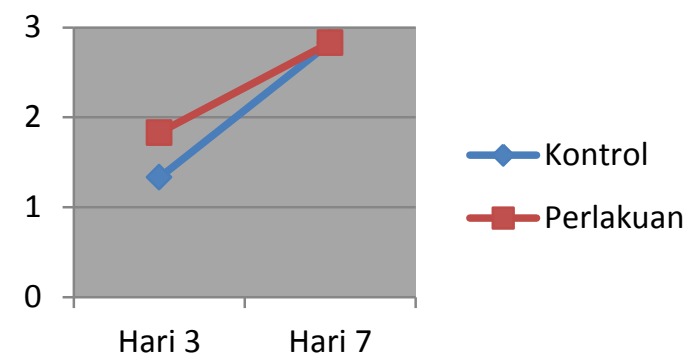

Gambar 5. Perbandingan tingkat infeksi.

\section{PEMBAHASAN}

Tujuan utama pengobatan luka adalah mengembalikan fungsi dan bentuk jaringan kulit kembali normal dengan komplikasi lokal seminimal mungkin. Pada saat terjadi luka, jaringan tersebut akan mengalami proses penyembuhan yang merupakan fenomena yang kompleks dan melibatkan beberapa proses.

Selama tahap penyembuhan luka, angiogenesis berperan dalam penyediaan zat makanan dan oksigen pada daerah luka serta meningkatkan pembentukan jaringan granulasi. Fakor pertumbuhan utama dalam angiogenesis adalah vascular endothelial growth factor (VEGF) yang dihasilkan oleh sel endotel dan fibroblast. Fibroblast sendiri berperan terhadap sintesis, 
deposisi dan remodelling dari matriks ekstraseluler. Setelah bermigrasi ke lokasi luka, fibroblast akan mulai sintesis matriks ekstraseluler. Kolagen merupakan protein utama dari matriks ekstraseluler dan berperan besar dalam penyembuhan luka ${ }_{(28)}$.

Penelitian ini merupakan riset dasar yang bertujuan untuk menilai pengaruh Culture filtrate Fibroblast (CFF) terhadap penyembuhan luka. Pengamatan dilakukan pada hari ke-3 dan ke-7. Objek penelitian adalah tikus putih galur wistar dimana setiap kelompok terdiri dari enam ekor tikus. Analisis dilakukan terhadap tingkat penyembuhan yang ditentukan luasnya restriksi luka, derajat pembentukan kolagen, fibrosis, pembuluh darah baru, epitelisasi dan infeksi. Lima indikator terakhir merupakan analisis mikroskopis yang dilakukan oleh ahli patologi yang berpengalaman.

Secara umum pada kedua kelompok ditemukan adanya proses penyembuhan luka yang ditandai dengan peningkatan skor indikator penyembuhan seperti pembentukan kolagen, vaskularisasi, fibrosis dan epitelisasi pada hari ke-7 yang berbeda dengan hari ke-3 serta peningkatan restriksi jaringan. Kondisi ini mengandung pemahaman bahwa proses penyembuhan terjadi secara alami. Penelitian CFF itu sendiri ditujukan untuk menilai apakah CFF dapat mempercepat proses penyembuhan yang terjadi yang ditandai dengan peningkatan indikator penyembuhan dan besarnya perubahan restriksi jaringan.

Penelitian ini memperlihatkan tingkat penyembuhan luka tidak berbeda pada hari ke-3, namun berbeda pada hari ke-7 dimana perubahan diameter restriksi lebih besar ditemukan pada kelompok yang mendapat CFF dibanding $\mathrm{NaCl}$. Hasil ini didukung dengan data mikroskopis, dimana pada hari ke-7 semua skor indikator penyembuhan seperti pembentukan kolagen, vaskularisasi, fibrosis dan epitelisasi lebih tinggi pada kelompok yang mendapat CFF, walaupun secara statistik yang berbeda secara bermakna hanya indikator fibrosis. Hasil ini memperlihatkan bahwa CFF berperan besar dalam mempercepat penyembuhan luka.

Tidak ditemukannya perbedaan pada hari ke-3 diduga berkaitan dengan dengan belum sempurnanya atau jumlah mediator penyembuhan luka belum optimal untuk menjamin proses penyembuhan luka. Pada hari ke-7 diduga komponen yang terdapat di dalam CFF sudah mampu menginduksi sel-sel sekitar untuk menghasilkan mediator penyembuhan dalam jumlah optimal.

CFF terdiri dari berbagai protein yang dihasilkan oleh sel fibroblat, dimana komponen utama adalah Fibroblast Growth Factor (FGF). Disamping itu, CFF juga mengandung Vascular Endothelial Growth Factor (VEGF), serta sitokin dan kemokin yang berperan dalam proses penarikan sel-sel radang. Hal ini menjadi dasar peningkatan kecepatan penyembuhan luka serta peningkatan skor indikator penyembuhan setelah pemberian CFF. CFF juga menginduksi aktivitas sel miofibroblast yang berperan dengan konstriksi jaringan pada penyembuhan luka.
Montesano dkk (1986) melaporkan bahwa FGF merupakan salah satu mediator penyembuhan yang dihasilkan oleh sel fibroblast. FGF juga berperan dalam menginduksi aktivitas sel endotel serta mendorong migrasi endotel ke matriks kolagen untuk membentuk capillary like tubulus. Proses ini sangat berperan dalam induksi angiogenesis. Mekanisme ini memperlihatkan hubungan antara tingkat vaskularisasi yang ditemukan pada penelitian ini dengan pemberian CFF.

Pembentukan kolagen lebih banyak ditemukan pada kelompok yang mendapat CFF dengan skor hampir mendekati dua. Skor ini memperlihatkan kepadatan kolagen hampir sama dengan jaringan normal. Kondisi ini dapat dijelaskan bahwa mediator yang terdapat di dalam CFF akan menginduksi aktivitas dan proliferasi sel fibroblast di jaringan luka. Fibroblast merupakan sel utama dalam menghasilkan kolagen yang berperan dalam penyembuhan luka, seperti kolagen tipe I (berperan dalam pembentukan fibrosis), III (granulasi) dan VIII (integritas jaringan). Disamping itu fibroblast juga menghasilkan fibronektin, yang bersama sama dengan kolagen menjadi penyusun matriks ekstraseluler.

Epitelisasi merupakan proses pembentukan epitel baru pada jaringan luka. Sejumlah penelitian memperlihatkan terdapat interaksi sel yang unik antara epitel, endotel dan fibroblast dalam proses penyembuhan luka. CFF yang kaya akan mediator penyembuhan akan menginduksi aktivitas ketiga sel. Hal ini juga memperlihatkan pengaruh CFF terhadap tingginya skor epitelisasi pada kelompok perlakuan.

Serbukan sel-sel radang pada dasarnya merupakan bagian dari tahapan penyembuhan luka pada fase inflamasi. Terdapat dua aspek sel radang yaitu mencegah infeksi dan memfagosit sel-sel mati yang terdapat di sekitar luka. Sejumlah penelitian memperlihatkan rendahnya konsentrasi sel radang pada luka berpengaruh terhadap risiko infeksi. Sejumlah penelitian membuktikan pemberian sel Fibroblast pada luka akan meningkatkan migrasi sel radang ke daerah luka. Pada penelitian ini ditemukan serbukan sel radang hampir sama pada kelompok kontrol dan perlakuan. Namun demikian, tidak ditemukan tanda-tanda infeksi pada kedua kelompok.

$\begin{array}{lcr}\text { Analisis data yang dilakukan pada } \\ \text { penelitian ini } \\ \text { kecenderungan } & \text { memperlihatkan adanya } \\ \text { peningkatan } & \text { indikator }\end{array}$
penyembuhan luka pada kelompok yang mendapat $\mathrm{CFF}$, walaupun hanya fibrosis yang memperlihatkan perbedaan yang bermakna. Hasil ini secara sederhana memperlihatkan bahwa CFF cukup berpotensi dalam mempercepat penyembuhan luka. Namun demikian, besarnya konsentrasi CFF yang dibutuhkan tidak diketahui, karena penelitian ini hanya mengidentifikasi pengaruh CFF secara umum tanpa mempertimbangkan pengaruh konsentrasi.

Berdasarkan hasil penelitian dapat disimpulkan hal berikut, yaitu CFF memberikan tingkat penyembuhan luka yang lebih baik dibanding $\mathrm{NaCl}$ yang ditandai dengan adanya perbedaan perubahan restriksi jaringan yang lebih 
besar. Pembentukan kolagen, epitelisasi, pembuluh darah baru dan fibrosis lebih banyak ditemukan pada kelompok CFF, walaupun nilai yang berbeda secara bermakna hanya pada fibrosis. Migrasi sel radang ditemukan sama pada kedua kelompok teliti.

\section{KEPUSTAKAAN}

1. Barbul, A and Efron, D. Wound Healing in Schwartz principle of surgery $9^{\text {th }}$ ed. McGrawHill. New York. 2010; 210 - 219.

2. Menke N, Ward K, Witten T, Bonchev D, Diegelman R. Impaired wound healing. Clin Dermatol. 2007; 25:19-25.

3. Ankush $\mathrm{G}$ and Dipetro L. Aging and Wound Healig; World Journal Surgery. 2004; 28:321-326.

4. Marcovitch H. Black's Medical Dictionary, $41^{\text {st }}$ ed. A\&C Black. London. 2005; 281.

5. Kumar $P$ and Clark M. Androgen modulate the inflammatory response during acute wound healing, penerbit Manchester, UK. 2005; 110.

6. Herwiyanti S, Ghufron M, Budiono B. Pengaruh pemberian lidah buaya (aloevera) pada kultur fibroblast embrio ayam. Jurnal berkala ilmu kedokteran XXX(2); 1998.

7. Mathieu D, Linke J, Wattel F. Non Healing Wounds. In: Handbook on hyperbaric medicine, Mathieu DE, editor. Netherlands: Springer, PP. 2006; 401-427.

8. Broughton $\mathrm{G}$, Janis J, Attinger $\mathrm{C}$. The basic science of wound healing, department of plastic surgery, University of texas shouthwestern medical center. 2006; 509528.

9. Campos A, Groth A, Branco A. Assesment and nutritional aspects of wound healing. Curr Opin Clin Nutr Metab Care. 2008; 11: 281-288.

10. Meszaros A, Heier M, Bannasch H, Stark G. Macrophage interactions with neutrophils during acute inflammation, Brown university. 2000; 435-441.

11. Mosser D and Edwards J. Exploring the full spectrum of macrophage activation. Nature reviews Immunology. 2008; 8: 958-969.

12. Jameson $J$ and Havran W. Skin gammadelta T-cell functions in hemostasis and wound healing, Department of Immunology. 2007; 215: 114-122.

13. Mills R, Taylor K, Podshivalka K, McKay D, Jameson J. Defect in Skin gamma delta $T$ cell function contribute to delayed wound repair in rapamicin treated mice. $\mathrm{J}$ Immunol. 2008; 181: 3974-3983.

14. Purnami. Peran fibroblast pada penyembuhan luka. Malang; 2003.

15. Park JE and Barbul A. Understanding the role of immune regulation in wound healing, Am J Surg. 2004; 187: 11-16.

16. Swift M, Burn A, Gray K, DiPietro L. Agerelated alterationsin the inflammatory response to dermal injury. J Invest Dermatol. 2001; 117:1027-1035.

17. Gawronska-Kozak B, Bogacki M, Rim J, Monroe W, Manuel J. Scarless skin repair in immunodeficient mice. Wound Repair Regen. 2006; 14:265-276.

18. Fawcett Don W. Buku ajar histology, Penerbit buku kedokteran EGC: 2002; 132149.

19. Junqueir L, Carneiro J, Kelley R. Basic Histology; Appleton And Lange: 1998; 106119.

20. Carranza F, Newman M, Takei H, Klokkevold P. Carranza's clinical periodontology, Saunders Elsevier: 2002; 751-752.

21. Sodera $V$ and Saleh $M$. Ilustrasi ilmu bedah minor, Bina rupa aksara: 1991; 112.

22. Robbins $S$ and Kumar V. Buku ajar patologi I $4^{\text {th }}$ ed. (Staf pengajar laboratorium patologi anatomi FK UI, penerjemah). EGC: 1995; 59.

23. Cormack D. Ham's histology. JB Lippincott Company: 1994; 220.

24. Eroshenko V. Atlas histology di Fiore dengan korelasi fungsional, $9^{\text {th }} \mathrm{ed}$. Penerbit buku kedokteran EGC: 2003; 30.

25. Gartner L and Hiatt J. Color textbook of Histology $2^{\text {nd }}$ ed, Saunders: 2001; 42.

26. Rachmawati $\mathrm{H}$, Beljaars L, Reker-Smit C, Van Loenen-Weemaes AM, Hagens WI, Meijer DK, Polresta K. Pharmacokinetic and biodistribution profile of recombinant human interleukin-10 following intravenous administration in rats with extensive liver fibrosis. Pharm Res (NY): 2006; 7.

27. Sabiston D. Textbook of Surgery $18^{\text {th }}$ ed, WB Saunder; 2008.

28. Martin D, Rojo A, Salinas M, Diaz R, Galardo $G$. Regulation of heme oxygenase-1 expression through the phosphatidylinositol 3 kinase/Akt Pathway and the Nrf2 transcription factor in response to the antioxidant phytochemical, carnosol. JBC paper, 2003 Des 19. 